\title{
Temporal changes in proportions of small mammals in the diet of the mammalian and avian predators in Slovakia
}

\section{Ján OBUCH}

Botanical Gardens of the Comenius University, SK-038 15 Blatnica, Slovakia; obuch@rec.uniba.sk

received on 28 February 2020

\begin{abstract}
The paper presents a brief account of the temporal changes found in proportions of the mammal components in the diets of several species of predators (owls and carnivores) collected from various sites in Slovakia and originating in various periods (Late Pleistocene-Recent). The material collected from the Šarkanica Cave (Muráňska planina Mts.) contained bones in three layers, dated using the radiocarbon analysis $\left({ }^{14} \mathrm{C}\right)$ to $18,000-21,000$ years $\mathrm{BP}(18-21 \mathrm{Ka})$, showing relatively small differences in composition of the fossil diet of Bubo scandiacus with predominance of Lasiopodomys gregalis $(73.3 \%)$ and Chionomys nivalis (6.9\%). A similar type of material from the Nový 3 Cave (Belianske Tatry Mts.), dated to the period of $30 \mathrm{Ka}$, contained more numerous remnants of Lemmus cf. lemmus and Sorex tundrensis. Undated samples from the Nový 1 Cave and from the Šarkania diera Cave (Súl'ovské skaly Mts.), which differ in their higher abundance of Dicrostonyx cf. gulielmi, are probably dated from the colder period of the last glacial maximum. Three samples from caves in the Vel'ká Fatra Mts. dated from the Late Pleistocene (Upper Dryas) originated from carnivores, with differences in relative proportions of predominant prey species: Chionomys nivalis $(80.0 \%)$ and Lasiopodomys gregalis $(14.3 \%)$, while remains of Cricetus cricetus $(0.6 \%)$ also appear there. Two examples of differences in the diet composition of Strix aluco in the Vel'ká Fatra Mts. are present in samples dated to the Holocene period: natural development of forest fauna in the environs of Dolný Harmanec and anthropogenic influence in the form of three deforestation periods in the Tlstá massif near Blatnica (both Vel'ká Fatra Mts.). A sample set of the diet of Tyto alba dated $>500$ years BP from a church in Žilina is compared with a recent sample set of this owl diet from the Turčianska kotlina Basin and from the Danubian Lowland (Tekovské Lužany). The main difference lies in the greater proportion of the murid rodents and the relatively lower abundance of Microtus arvalis in the sample from the 16th century. Similar results were found comparing samples of Tyto alba diet, taken from a cave near Hatiny (Slovenský kras Mts.) and expected to be 100 years old, with more recent samples from the Košická kotlina Basin. The collection from the Hatiny Cave differs from the recent material in the presence of Sicista trizona and Alexandromys oeconomus. The recent samples of the diet of Bubo bubo taken from the Horné Považie Basin differ from the samples dated back more than 70 years ago by a high proportion of the genus Apodemus and a predominant incidence of frogs, while the old samples come from the period of the communist influence of the agricultural production causing serious environmental changes in the countryside (1950s) and as a result, a greater volume of large prey species, Rattus norvegicus, Arvicola amphibius, Lepus europaeus, and Erinaceus roumanicus. Since 1990, the availability of large prey for Bubo bubo has decreased due to the decline of livestock farming and a consequent successional overgrowing of pasture land by trees.
\end{abstract}

Key words. Small mammals, Slovakia, Late Pleistocene, Holocene, diet of owls. 


\section{INTRODUCTION}

Remembering the legacy of Helmuth SchAEFER (ОвUCн 2012), we decided to revive his idea of seeking out old, quantitatively rich osteological findings originating from the diet of owls. This is how he has influenced our research approach, particularly the way he used to look for fossil nests made by snowy owls (Bubo scandiacus) and then the process of his searching for bones from the entrance to the Muránska jaskyňa Cave in the Belanské Tatry Mts. (SCHAEFER 1974, 1975). The advantage of these findings lies in the possibility of comparison of their contents with the samples of diet of the same predator taken in recent years.

The first data set came from samples of the tawny owl (Strix aluco) diet from the Gaderská dolina Valley in the Vel'ká Fatra Mts. in northern Slovakia (OBUCH \& DAROLA 1985), later supplemented by findings made in the environs of Dolný Harmanec situated nearby (ОвUCH 2006a, 2011), on the opposite slope of the Vel'ká Fatra Mts. An older finding of the barn owl (Tyto $a l b a)$ food remains near Hatiny in the Slovenský kras Mts. (ОвUCH 1992) was complemented with other findings from the church of Saint Stephen the King in Žilina (OвUCH \& DoricA 2011 ) and then compared with more recent diet samples (ОвUCH et al. 2016). Differences in the composition of the eagle owl (Bubo bubo) diet suggesting changes over three successive time periods were assessed based on samples from the Belianske Tatry Mts. (OBUCH 2002), the Žilina Basin (Овuсн 2017), valleys of the Upper Váh River (OBUCH 2018) and the Liptov Region (KudLA et al. 2019). The first published case of an original fossil nest belonging to the snowy owl (Bubo scandiacus) came from the Súl'ovské skaly Mts. (ОвUCH 2000). We also reported a finding of such nest from the Muránska planina Mts. (OBUCH 2006b). A finding of fossil bones left originally by carnivores in the Suchá 3 Cave in the Belianska dolina Valley (KADLEČ́́K et al. 1995) was later supplemented with similar findings from another two caves in the Vel'ká Fatra Mts. (Овuch 2019).

All the data from these findings took on new significance, since several samples were dated using the radiocarbon method (KAISER et al. 2018). With the possibility to assign particular findings to certain periods, the differences between temporal sample sets could help to describe changes in the composition of the diet of particular predators and finally, to describe development of environments in the periods between the Late Pleistocene and Holocene and obtain an evidence of the environmental changes linked both to natural and anthropogenic influences.

\section{MATERIAL AND METHODS}

Diet of Bubo scandiacus

Fossil nests of the snowy owl (Bubo scandiacus) were found according to the instructions by Helmut SchaEFER (1912-1976), with whom we collected bones in the Nový 1 Cave (1,409 m a. s. 1.) in the Belianske Tatry Mts. (northern Slovakia) in October 1975. This sample set was lost after ScHAEFER's death, so in 2011 we additionally gathered the remaining bones from the supposed nest site scattered at the same place, down to a depth of $30 \mathrm{~cm}$. Additional collections were made in the caves with large entrances, situated in the slope beneath the Nový 1 Cave. The nest remains were bowl-shaped sites around $40 \mathrm{~cm}$ in diameter, and were usually located $1 \mathrm{~m}$ from the cave walls.

The finding in the Šarkanica Cave (925 m a. s. 1.) in the Muránska planina Mts. (central Slovakia), was made on 11 October 1982, and a sample of bones was taken. Another visit on 25 October 1983 led to the discovery of three layers supposedly representing former nests of the snowy owl (Fig. 1): the thickest level on the left from the entrance was divided into a lower layer (sample Ba-1053, dated with ${ }^{14} \mathrm{C}$ to the period 21,170 \pm 220 years BP) and an upper layer (sample Ba-158, dated to the age of $19,640 \pm 330$ years 
BP). The level corresponding to another (second) nest is ca. $5 \mathrm{~cm}$ higher than the former layers and situated on the right from the entrance (sample Ba-1059, dated to the age of $17,970 \pm 600$ years BP). The third level was situated at the bottom, on the right side of the entrance to the cave (sample Ba-1060, dated to 20,510 \pm 580 years BP). In the Nový 3 Cave (1,791 m a. s. 1.; Belianské Tatry Mts.), an additional sample of bones was taken from the place where SCHAEFER collected bones aged according to radiocarbon dating at 30,000 years BP (SCHAEFER 1974, 1975). The only prey item published from his collection were shrews (Soricidae), while the other prey items were omitted (SCHAEFER 1975). The finding of supposed remains of the snowy owl nest in the Sarkania diera Cave $(590 \mathrm{~m}$ a. s. 1.) in the Súl'ovské skaly Mts. (north-western Slovakia) made in 1976 was described by Овисн (2000).

\section{Diet of carnivores}

Fossil bones originating from the diet of carnivores are characterized by their considerable fragmentation, a result of chewing and digestion by the predator. We found such remnants deep in the caves with narrow entrances, in the former dens of carnivores, most likely the species of foxes such as Vulpes vulpes or Vulpes lagopus. In a small chamber of a cave in the Hrdošná skala Rock (850 m a. s. 1.; Vel'ká Fatra Mts., north-western Slovakia) I found a $5 \mathrm{~cm}$ thick layer of bones beneath a $1-2 \mathrm{~cm}$ thick cover of a white sinter

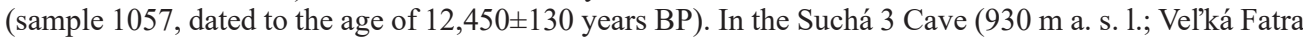
Mts.) I found bones washed down to the end of the main passage of the cave in a mixture of older bones
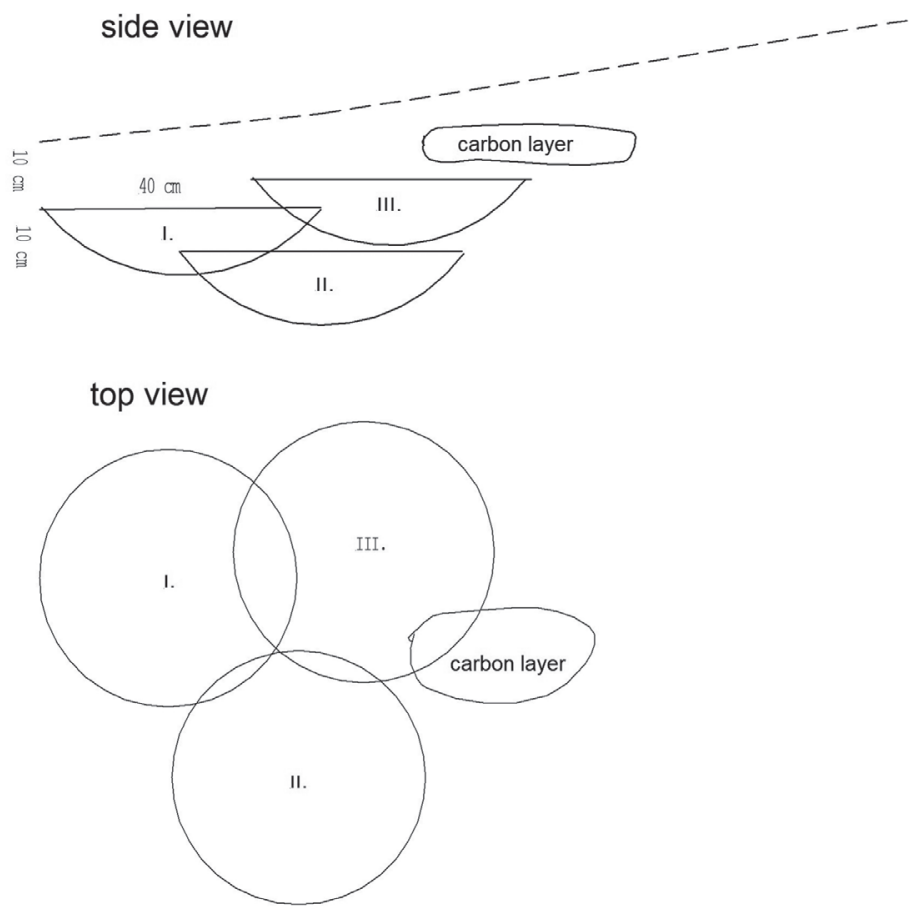

Fig. 1. Schematic outline of the locations of fossil nests of the snowy owl (Bubo scandiacus) in the Šarkanica Cave, Muráňska planina Mts., central Slovakia. 
of heavier forms such as the cave bears (Ursus spelaeus) together with a smaller amount of bones from the Holocene period (sample Ba-1071, dated to the age of 11,010 140 years BP). In the Biela Cave ( $850 \mathrm{~m}$ a. s. 1.; Vel'ká Fatra Mts.) I collected small bones together with others from the cave bear when excavating the cave bottom (BENDík 2018). For identification of the species of the Arvicolinae subfamily (voles and lemmings), we used the anterior lower molars $\left(\mathrm{M}_{1}\right)$, as complete jaws were usually not preserved.

\section{Diet of Strix aluco}

The bones of the Holocene age originating from the tawny owl (Strix aluco) prey are found in sites where the daytime lairs of these owls are located, in rocky places with overhangs, chimneys, and caves. The owl pellets fall to the ground beneath high-up lairs and settle into the soil layers. Beneath an overhang at Havranovo (Vel'ká Fatra Mts.), I found layers of bones reaching a depth of $90 \mathrm{~cm}$. The ages of the particular layers were determined by Vojen LožEK (1925-2020) based on the snail species composition (OBUCh \& DAROLA 1985). The ages of the pellet samples from the ground below the overhang were then taken to be similar to those of the specific soil layers. The finding from the Krpcovo Cave (Vel'ká Fatra Mts.), dated using the radiocarbon method (sample Ba-1072, estimated age 4,170 \pm 140 years BP), was located beneath a fallen boulder by the rear wall of the cave. A similar finding dating from the Sub-Boreal period was made beneath an overhang of a boulder in a part of the rocks above the Bystrická dolina Valley (Vel'ká Fatra Mts.). The bones from disintegrated owl pellets lying freely on the soil surface layer were ascribed to the sub-recent age. A recent material of the tawny owl prey comes from well-preserved pellets gathered there since 1976.

\section{Diet of Tyto alba}

Old bones from the prey of the barn owl (Tyto alba) were found in the church of Saint Stephen the King at Dolné Rudiny (municipality of Žilina, north-western Slovakia), hidden in two hollows inside the church, the old sockets of wooden beams which burnt out during a fire in the early 16th century (calibrated date $1490 \pm 30 \mathrm{AD}$ ). I compared this sample set with the data obtained from the recent period collected in the Turčianska kotlina Basin (northern Slovakia) and in the church at Tekovské Lužany (Podunajska nížina Lowlands; ОвUCH et al. 2016). In the ceiling of a cave near Hatiny (Slovenský kras Mts., eastern Slovakia), I found bones from a nest of the barn owl (calibrated date $1870 \pm 50 \mathrm{AD}$ ), which I compared with a recent sample set of pellets from this owl collected in the Košická kotlina Basin (eastern Slovakia; cf. ОвUсн et al. 2016).

\section{Diet of $B u b o \quad b u b o$}

The bones from nests of the eagle owl (Bubo bubo) are here separated into three periods of the supposed origin: (1) sub-recent (SR), from the nests abandoned in the 1970s and 1980s; (2) nests occupied in 1970-1990; (3) nests used after 1990. A nest found in the Sokol Rock near Slovenské Pravno in the western part of the Turčianska kotlina Basin (north-western Slovakia) was destroyed by a boulder falling onto the rocky shelf with the nest, and the bones were collected underneath of the boulder (calibrated date $1890 \pm 50 \mathrm{AD}$ ). This bone set was compared with the recent bone collections from the Sokol Rock and from the Moškovské skaly Rocks in the Mt. Žiar, $3.5 \mathrm{~km}$ away from the Sokol Rock. Deep in the valleys of the Nízke Tatry Mts. (northern Slovakia) I found eagle owl nests dating from the period of the deforestation and introduction of sheep farming to the mountains. The proportion of frog and mammal species found in their remnants are comparable with samples from the nests located on the borders of the upper part of the Liptovská kotlina Basin (northern Slovakia) dating from the sub-recent and recent periods.

\section{Methods}

Results are presented in the form of rearranged tables (Tables 1-9) with calculations of the marked differences from the mean (MDFM; OBUCH 2001). Blocks of species with positive differences $(1+, 2+)$ 
are highlighted with bold lines. Under the dashed line there are rather numerous species without marked differences, arranged from the most to the least numerous. Other less numerous species of mammals and other vertebrate taxa are not presented in the tables. The summaries of vertebrate groups consist of numbers of the mammal and bird species found. The Zber ("Collection") database software was used for compiling the tables (ŠIPÖcz 2004). The taxonomic nomenclature used is based on the latest editions of Mammals of the World (WILSON et al. 2016, 2017). Names of phases of the Holocene period are mentioned according to LožEK (1973).

\section{RESULTS AND DISCUSSION}

\section{Diet of $B u b o$ scandiacus}

A comparison of five sample set of bones collected from the Šarkanica Cave on the Muránska planina Plateau (Table 1), supposedly separated temporarily by a period of around 3,000 years (18-21 Ka), revealed no marked differences in the relative incidence of the dominant species, Lasiopodomys gregalis (73.3\%) and Chionomys nivalis $(6.9 \%)$. The oldest sample set con-

Table 1. The composition of fossil remains of diet of the snowy owl (Bubo scandiacus) from the Šarkanica Cave (Muráňska planina Mts., central Slovakia). Legend to the origin and age of particular sample sets: 1 - a mixture of samples from various positions of the cave, collected on 11 October 1982 and 25 October $1983 ; 2$ - the sample 1053 (Ia), age 21,170 220 years BP, collected on 25 October 1983; 3 - the sample 1058 (Ib), age 19,640 \pm 330 years BP, collected on 25 October 1983; 4 - the sample 1059 (III), from the position of the upper nest on the right side, age 17,970 1600 years BP, collected on 25 October 1983; 5 - sample 1060 (II), from the position of the bottom nest, age 20,510 \pm 580 years BP, collected on 25 October 1983

\begin{tabular}{|c|c|c|c|c|c|c|c|}
\hline $\begin{array}{l}\text { age (BP) } \\
\text { species } \backslash \text { sample No. }\end{array}$ & $\operatorname{mix}_{1}$ & $\begin{array}{c}21,200 \\
2\end{array}$ & $\begin{array}{c}20,500 \\
5\end{array}$ & $\begin{array}{c}19,600 \\
3\end{array}$ & $\begin{array}{c}18,000 \\
4\end{array}$ & total & $\%$ \\
\hline Myodes glareolus & $1+$ & 15 & 10 & 4 & 9 & 47 & 0.77 \\
\hline Microtus agrestis & $1+\quad 30$ & $1+102$ & $1-$ & 49 & $1-$ & 261 & 4.25 \\
\hline Alexandromys oеconomus & 30 & $1+90$ & 74 & $1-$ & 55 & 280 & 4.56 \\
\hline Sorex araneus & 5 & $1+\quad 13$ & $1-$ & 3 & 3 & 27 & 0.44 \\
\hline Sorex araneus novyensis & & 1 & 4 & & $1+$ & 13 & 0.21 \\
\hline Sorex tundrensis & $1-$ & 20 & 21 & 13 & 19 & 74 & 1.21 \\
\hline Lasiopodomys gregalis & $1-273$ & 780 & 1,434 & 874 & 1,139 & 4,500 & 73.31 \\
\hline Chionomys nivalis & 36 & 83 & 111 & 82 & 110 & 422 & 6.88 \\
\hline Ochotona pusilla & 5 & 8 & 10 & 7 & 6 & 36 & 0.59 \\
\hline Mustela nivalis & 3 & 8 & 9 & 7 & 9 & 36 & 0.59 \\
\hline Arvicola amphibius & 4 & 11 & 8 & 6 & 5 & 34 & 0.55 \\
\hline Mustela er & 1 & 6 & 2 & 2 & 3 & 14 & 0.23 \\
\hline Sicista betulina & 3 & 3 & 2 & 1 & 2 & 11 & 0.18 \\
\hline Neomys fodiens & & 3 & 1 & 4 & 1 & 9 & 0.15 \\
\hline Lepus timidus & & 1 & 1 & 2 & 2 & 6 & 0.10 \\
\hline Mammalia, 25 species & 404 & 1,149 & 1,731 & 1,089 & 1,418 & 5,791 & 94.35 \\
\hline Aves, $40+$ species & $2+\quad 77$ & 66 & $1-\quad 60$ & 55 & $1-\quad 57$ & 315 & 5.13 \\
\hline Amphibia, Reptilia, Pisces & $1+$ & 5 & 7 & 5 & 7 & 32 & 0.52 \\
\hline & 489 & 1,220 & 1,798 & 1,149 & 1,482 & 6,138 & 100.00 \\
\hline diversity (H') & 1.88 & 1.53 & 0.99 & 1.15 & 1.10 & 1.27 & \\
\hline
\end{tabular}


Table 2. Composition of fossil remains of diet of the snowy owl (Bubo scandiacus) from various sites of Slovakia

\begin{tabular}{|c|c|c|c|c|c|c|c|c|c|c|}
\hline \multirow{2}{*}{$\begin{array}{l}\text { age (ka BP) } \\
\text { species } \backslash \text { site } \\
\text { Lemmus lemmus }\end{array}$} & \multicolumn{2}{|c|}{$\begin{array}{c}30-32 \\
\text { Nový } 3\end{array}$} & \multicolumn{2}{|c|}{ Nový 1} & \multicolumn{2}{|c|}{ Šarkania diera } & \multicolumn{2}{|c|}{ 18-21 } & \multirow{2}{*}{$\begin{array}{r}\text { total } \\
69\end{array}$} & \multirow{2}{*}{$\begin{array}{r}\% \\
0.80\end{array}$} \\
\hline & $2+$ & 68 & & & & 1 & 4 & 0 & & \\
\hline Sorex tundrensis & $1+$ & 48 & & & $1-$ & 1 & & 74 & 123 & 1.42 \\
\hline Dicrostonyx gulielmi & $1-$ & 25 & $4+$ & 81 & $2+$ & 69 & $5-$ & 2 & 177 & 2.50 \\
\hline Chionomys nivalis & $1-$ & 44 & & 10 & $1+$ & 60 & & 422 & 536 & 6.21 \\
\hline Sorex araneus & $1-$ & 2 & & & $1+$ & 11 & & 27 & 40 & 0.46 \\
\hline Sorex caecutiens & & & & & $1+$ & 6 & $1-$ & 0 & 6 & 0.07 \\
\hline Microtus agrestis & $3-$ & 6 & $1-$ & 0 & $3-$ & 0 & $1+$ & 261 & 267 & 3.90 \\
\hline Alexandromys oеconomиs & $1-$ & 32 & $2-$ & 0 & $3-$ & 0 & $1+$ & 280 & 312 & 3.61 \\
\hline Ochotona pusilla & $1-$ & 2 & & 1 & & 7 & & 36 & 46 & 0.53 \\
\hline Lasiopodomys gregalis & & 1,355 & $1-$ & 102 & & 394 & & 4,500 & 6,351 & 73.56 \\
\hline Myodes glareolus & & 6 & & & & & & 47 & 53 & 0.61 \\
\hline Mustela nivalis & & 5 & & & & 6 & & 36 & 47 & 0.54 \\
\hline Arvicola amphibius & & 5 & & 1 & & 1 & & 34 & 41 & 0.47 \\
\hline Sorex araneus novyensis & & 7 & & & & & & 13 & 20 & 0.23 \\
\hline Mustela erminea & & 2 & & & & & & 14 & 16 & 0.19 \\
\hline Sicista betulina & & 1 & & & & & & 11 & 12 & 0.14 \\
\hline Lepus timidus & & 1 & & 3 & & 1 & & 6 & 11 & 0.13 \\
\hline Neomys fodiens & & 1 & & & & & & 9 & 10 & 0.12 \\
\hline Microtus tatricus & & 1 & & & & 1 & & 3 & 5 & 0.06 \\
\hline Mammalia, 30 species & & 1,618 & & 198 & & 558 & & 5,791 & 8,165 & 94.57 \\
\hline Aves, $50+$ species & $1-$ & 39 & $2+$ & 38 & & 25 & & 315 & 417 & 4.83 \\
\hline Amphibia, Reptilia, Pisces & $1+$ & 17 & & 0 & & 3 & & 32 & 52 & 0.60 \\
\hline & & 1,674 & & 236 & & 586 & & 6,138 & 8,634 & 100.00 \\
\hline diversity (H') & & 0.97 & & 1.62 & & 1.23 & & 1.27 & 1.32 & \\
\hline
\end{tabular}

tains more numerous voles (Microtus agrestis, Alexandromys oeconomus) and the common shrew (Sorex araneus). The proportions of the subspecies Sorex araneus novyensis Schaefer, 1975 are higher in the younger sample sets. The oldest sample set has the highest value of species diversity $\left(\mathrm{H}^{\prime}=1.53\right)$, which may indicate the climatically warmest phase within the whole time period under comparison. The presence of certain mammals (Erinaceus, Talpa) and birds (Tetrao urogallus, Loxia curvirostra) suggests the existence of a sparse taiga forest in the area surrounding the Šarkanica Cave.

The oldest sample of the snowy owl diet from the Nový 3 Cave in the Belianske Tatry Mts. $(30 \mathrm{Ka})$ is characterized by high proportions of the Norway lemming (Lemmus cf. lemmus) and the tundra shrew (Sorex tundrensis; Table 2). The sample sets from the Novy 1 Cave and Šrkania diera Cave in the Súl'ovské skaly Mts. show a higher proportion of the lemming Dicrostonyx cf. gulielmi. The recent species of the genus, the Arctic lemming (Dicrostonyx torquatus), inhabits cold tundra along the coast of the Arctic Ocean, which suggests that these two undated sample sets originated in the cold period of the last ice age between the warmer phases from which the samples from the Nový 3 and Šarkanica Caves come. 
The sample sets of the snowy owl prey of the Pleistocene age contained bone fragments of large mammals, indicating that the owls consumed their cadavers. PORTENKO (1972) reported remains of the reindeer and large domestic mammals in the snowy owl pellets from the Recent. Compared with the bones found in the eagle owl nests, the jawbones present at the former sites were more broken up. This was also suggested by results of the study by RoYER et al. (2019), who investigated the degree of brokenness of recent-period bones associated with various species of predators.

The snowy owl pellets found in northern Norway have produced material in which more than 1500 prey items have been identified (ОвUCH \& BANGJORD, unpubl. data). Similarly as in the Pleistocene material from Slovakia, the analysis of the Norwegian material revealed a great predominance of mammals $(92.8 \%)$, but birds were also present $(5.3 \%)$ as well as amphibians $(1.8 \%)$. The predominant species was the Norway lemming (Lemmus lemmus; 60.0\%). The short-tailed vole (Microtus agrestis; 9.8\%) and the root vole (Alexandromys oeconomus; 5.9\%) were more abundantly represented in the Norwegian material than in the fossil material from Slovakia.

\section{Diet of carnivores}

Prior to the last global cooling (Late Dryas period) there were two warm interstadials (Bølling and Allerød periods), during which the relative incidence of dominant prey species changed: our samples from the diet of cave carnivores from the Vel'ká Fatra Mts. show that the snow vole (Chionomys nivalis) was a more numerous prey (80.0\%) than the narrow-headed vole (Lasiopo-

Table 3. Composition of fossil remains of diet of carnivores in the caves of the Vel'ká Fatra Mts., northern Slovakia

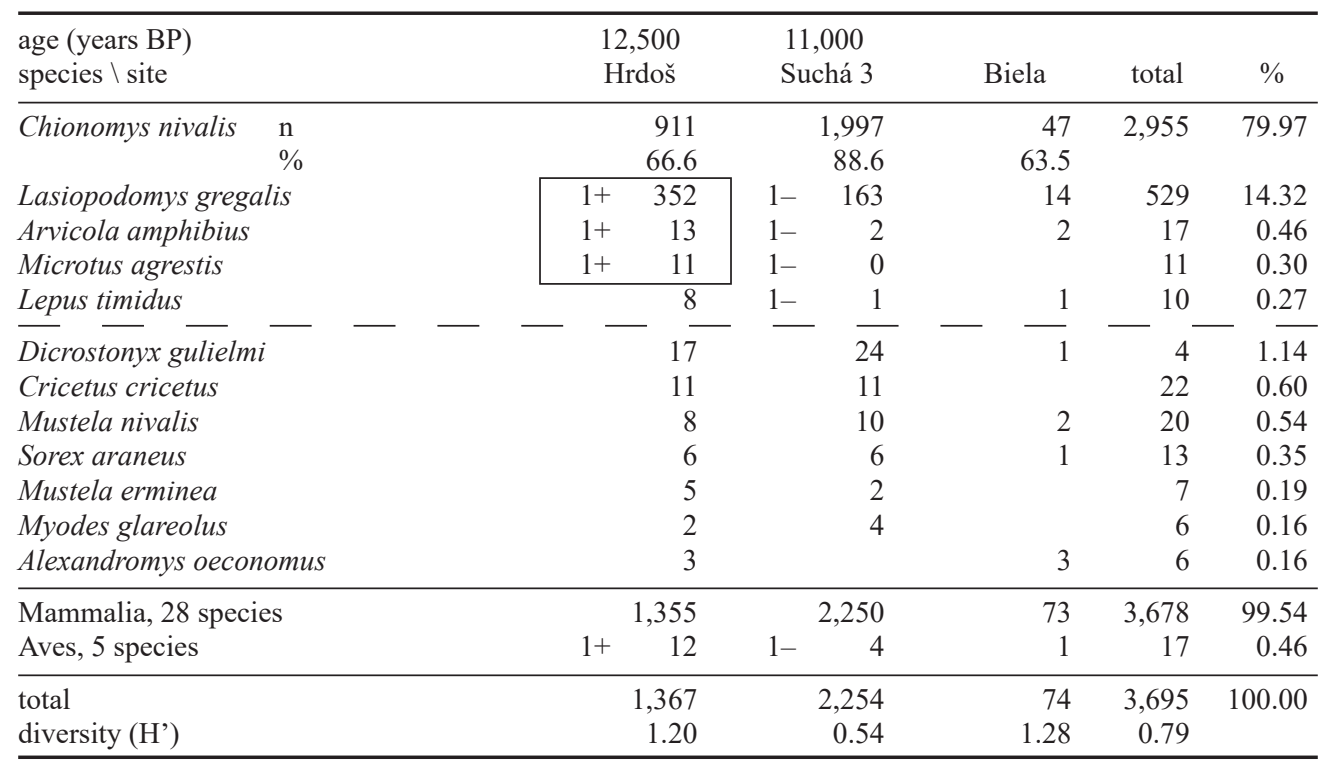


domys gregalis; $14.3 \%$ ). They also feature the psychrophilic species Dicrostonyx gulielmi, but also the steppe species, the common hamster (Cricetus cricetus; Table 3). An older sample from the cave in the Hrdošná skala Rock is more strongly influenced by the preceding warmer period: it is characterized by greater species diversity $\left(\mathrm{H}^{\prime}=1.02\right)$ and high representation of several vole species (Lasiopodomys gregalis, Arvicola amphibius, Microtus agrestis). A more recent sample set from the Suchá 3 Cave appears to be dated to the culminating period of the colder Late Dryas period. It shows a low species diversity $\left(\mathrm{H}^{\prime}=0.54\right)$ with a great predominance of the snow vole (Chionomys nivalis; 88.6\%). In a small undated sample set from the Biela jaskyn̆a Cave, the species composition is similar to the average value from the previous two findings.

Judging from the degree of brokenness of bones found deep in the caves, they originated more likely from the prey of red foxes (Vulpes vulpes) than of the snow fox (Vulpes lagopus), see e.g. Royer et al. (2019). In the cave at the Hrdošná skala Rock I found bones in an original form, forming an almost undisturbed layer, while in the Suchá 3 Cave the bones were displaced by running water, and contaminations with a recent organic plant material may have influenced the results of radiocarbon dating. The latter sample set of bones was found together with others coming from the cave bear (Ursus spelaeus), which was already extinct in central Europe in the Late Dryas period (SABOL et al. 2014). The small admixture of the remains of bats in the sample set comes from the Holocene period. Mounds of almost intact bat skeletons found in the caves seem to be stashes of food left by the pine marten (Martes martes), for details see ОвUсн (1995).

\section{Diet of Strix aluco}

The analysis of the findings of prey remnants of the tawny owl (Strix aluco) in the environs of Dolný Harmanec document the natural development of forest fauna during the Holocene period from the time before serious anthropogenic impact on the local environment and then through three periods of intensive deforestation and livestock farming in the Tlstá Massif.

A sample set from the Krpcovo Cave in the Bystrická dolina Valley, dated to the Epi-Atlantic period, confirmed the survival of the Pleistocene faunal elements such as the voles Chionomys nivalis and Lasiopodomys gregalis in the medium-high mountain positions (at ca. $800 \mathrm{~m} \mathrm{a.s.1.)}$ after the end of the warm and moist Atlantic period (Table 4). The dry Epi-Atlantic period was dominated by forest rodent species, like Apodemus flavicollis and Myodes glareolus, but non-forest species also penetrated into the mountains, such as Apodemus uralensis, A. sylvaticus, and Crocidura leucodon. In the sample set from the Krpcovo Cave, 15 species of bats were identified, predominantly the petrophilous species Vespertilio murinus and Nyctalus noctula, and the thermophilic species, represented by Miniopterus schreibersii. The owls also hunted bats in the sub-recent period, for instance in the entrance area of the Harmanecká jaskyňa Cave, where twelve bat species were found, primarily Myotis myotis. The tawny owls abandoned this cave when it was made publicly accessible in the 1950s, and sample sets gathered in the environs of the cave entrance in the period 1980-2006 only seldomly contained bat remains. Since 2015, the tawny owls have renewed their occupation of the entrance chamber of the cave (Izbica) during winter time when the cave is closed for the public, and bat bones are once again dominant components in the content of their pellets.

The lower horizons of the excavations in the Havranovo Valley in the Tlstá Massif, just $3 \mathrm{~km}$ outside the Turčianska kotlina Basin, dated to the Boreal period, were dominated by the Pleistocene species, like Lasiopodomys gregalis, Dicrostonyx gulielmi, and Chionomys nivalis, but 
Table 4. Proportions of particular mammal species in fossil remains of diet of the tawny owl (Strix aluco) of different age of the Holocene period from the environs of Dolný Harmanec (Vel'ká Fatra Mts., northern Slovakia)

\begin{tabular}{|c|c|c|c|c|c|c|c|c|c|c|}
\hline \multirow{2}{*}{$\begin{array}{l}\text { age (years BP) } \\
\text { species } \backslash \text { period } \\
\text { Chionomys nivalis }\end{array}$} & \multicolumn{2}{|c|}{4,200} & \multicolumn{2}{|c|}{ Sub-Boreal } & \multicolumn{2}{|c|}{ Sub-Recent } & \multicolumn{2}{|c|}{ Recent } & \multirow{2}{*}{$\begin{array}{r}\text { total } \\
30\end{array}$} & \multirow{2}{*}{$\begin{array}{l}\% \\
0.37\end{array}$} \\
\hline & $2+$ & 30 & & & $1-$ & 0 & $2-$ & 0 & & \\
\hline Lasiopodomys gregalis & $1+$ & 15 & & 2 & & & $2-$ & 0 & 17 & 0.21 \\
\hline Apodemus uralensis & $1+$ & 8 & & & & & $1-$ & 0 & 8 & 0.10 \\
\hline Sorex minutus & $1+$ & 41 & & 2 & & 13 & $1-$ & 30 & 86 & 1.70 \\
\hline Vespertilio murinus & $2+$ & 180 & $1-$ & 4 & $1-$ & 26 & $3-$ & 21 & 231 & 2.88 \\
\hline Nyctalus noctula & $2+$ & 113 & & 8 & $1-$ & 13 & $3-$ & 7 & 141 & 1.76 \\
\hline Rhinolophus hipposideros & $2+$ & 73 & & & $1-$ & 6 & $2-$ & 9 & 88 & 1.10 \\
\hline Pipistrellus pipistrellus & $1+$ & 101 & $1-$ & 2 & $1-$ & 34 & $1-$ & 89 & 226 & 2.82 \\
\hline Plecotus auritus & $2+$ & 72 & & & $1-$ & 11 & $3-$ & 2 & 85 & 1.60 \\
\hline Barbastella barbastellus & $1+$ & 50 & & & & 19 & $2-$ & 9 & 78 & 0.97 \\
\hline Miniopterus schreibersii & $1+$ & 15 & & & & & $1-$ & 0 & 15 & 0.19 \\
\hline Myotis bechsteinii & $1+$ & 15 & & & & 9 & $1-$ & 5 & 29 & 0.36 \\
\hline Eliomys quercinus & & & $1+$ & 5 & & 2 & & 2 & 9 & 0.11 \\
\hline Talpa europaea & $1-$ & 15 & $1+$ & 19 & $1+$ & 66 & $1-$ & 59 & 159 & 1.98 \\
\hline Muscardinus avellanarius & $1-$ & 75 & $1+$ & 29 & $2+$ & 146 & & 246 & 496 & 1.19 \\
\hline Myodes glareolus & & 395 & $1+$ & 103 & $1+$ & 473 & & 947 & 1,918 & 23.93 \\
\hline Sorex araneus & & 52 & & 17 & $1+$ & 85 & & 131 & 285 & 1.56 \\
\hline Microtus subterraneus & & 37 & & 6 & $1+$ & 55 & $1-$ & 48 & 146 & 1.82 \\
\hline Microtus arvalis & $2-$ & 0 & & & $1+$ & 15 & & 27 & 42 & 0.52 \\
\hline Myotis myotis & $3-$ & 4 & & 2 & $2+$ & 88 & $1-$ & 63 & 157 & 1.96 \\
\hline Eptesicus serotinus & & 17 & & 4 & $1+$ & 19 & $1-$ & 10 & 50 & 0.62 \\
\hline Glis glis & $2-$ & 7 & & 10 & & 40 & $1+$ & 124 & 181 & 2.26 \\
\hline Apodemus flavicollis & & 302 & $1-$ & 40 & & 280 & & 932 & 1,554 & 19.39 \\
\hline Myotis brandtii & & 8 & & & & 6 & $1-$ & 2 & 16 & 0.20 \\
\hline Microtus agrestis & & 10 & & & & 2 & & 11 & 23 & 0.29 \\
\hline Arvicola amphibius & & 1 & & 3 & & 6 & & 12 & 22 & 0.27 \\
\hline Sorex alpinus & & 5 & & & & 5 & & 11 & 21 & 0.26 \\
\hline Neomys fodiens & & 3 & & 1 & & 5 & & 8 & 17 & 0.21 \\
\hline Microtus tatricus & & 2 & & 1 & & 3 & & 5 & 11 & 0.14 \\
\hline Crocidura leucodon & & 4 & & 1 & & 2 & & 1 & 8 & 0.10 \\
\hline Myotis mystacinus & & & & & & 3 & & 5 & 8 & 0.10 \\
\hline Myotis blythii & & 1 & & & & 4 & & 1 & 6 & 0.07 \\
\hline Apodemus sylvaticus & & 4 & & 1 & & & & 1 & 6 & 0.07 \\
\hline Dryomys nitedula & & 4 & & & & & & & 4 & 0.05 \\
\hline Mammalia, 48 spec & & 1,673 & & 260 & & 1,449 & & 2,822 & 6,204 & 77.40 \\
\hline Aves, $47+$ species & & 42 & $1+$ & 16 & & 45 & & 111 & 214 & 2.67 \\
\hline Amphibia, Reptilia, Pisces & $1+$ & 134 & $1+$ & 40 & & 88 & & 199 & 461 & 5.75 \\
\hline Evertebrata & $7-$ & 0 & $3-$ & 4 & $2-$ & 48 & $1+$ & 1,084 & 1,136 & 14.17 \\
\hline tot: & & 1,849 & & 320 & & 1,630 & & 4,216 & 8,015 & 100.00 \\
\hline diversity (H') & & 2.81 & & 2.45 & & 2.62 & & 2.30 & 2.70 & \\
\hline
\end{tabular}


the forest species Apodemus flavicollis and Muscardinus avellanarius also appeared there, their occurrence was more numerous in the sample sets originating in the later parts of the Holocene (Table 5). The natural development of the forest fauna was seriously disturbed in the EpiAtlantic and Sub-Atlantic periods through the burning of the forests and subsequent pasturing of livestock by people in the Late Stone Age (Aeneolithic) and the Iron Age (La Tène), leading to the appearance of the non-forest rodent species, mainly of Apodemus uralensis, Cricetus cricetus, Eliomys quercinus, and Mus musculus. The diet of Strix aluco in these periods was characterized by a high diversity of the mammal and bird species ( $\left.\mathrm{H}^{\prime}>3\right)$, which could be an evidence of a mosaic-like landscape consisting of forest and pasture components. The last phase of deforestation in the slopes of the Tlstá Massif in the Sub-Recent period (Wallachian colonisation, 16th-19th century) was connected with a reduction in species diversity in the tawny owl prey $\left(\mathrm{H}^{\prime}=2.25\right)$ and dominance of the non-forest rodents, Microtus arvalis and Apodemus sylvaticus. The recent period is characterized by the dominance of the sylvan species Apodemus flavicollis, Myodes glareolus, and Sorex araneus in the tawny owl diet, and a small proportion of the non-forest species.

Remains of the forest dormouse (Dryomys nitedula) were found in the tawny owl pellets from the Vel'ká Fatra Mts. only in the samples from the mid-Holocene period. No such finding has been made from the Sub-Recent and Recent materials. The samples of the garden dormouse (Eliomys quercinus) were found in the mid-Holocene (Epi-Atlantic) material, and they werer confirmed also in the fresh tawny owl pellets collected near Dolný Harmanec in 2004 and near Blatnica between 2015 and 2020. The endemic Tatra pine vole (Microtus tatricus) has been identified in both Holocene sample sets collected in the Vel'ká Fatra Mts.

In the previous presentation of my findings of sub-fossil samples of the diet of Strix aluco in the Vel'ká Fatra Mts. (see OвUсн 2006a, 2011), I assumed that the sample set from the Krpcovo Cave came from the Early Atlantic period. However, the radiocarbon dating $(4,200$ years BP) shifted such assumption of the survival of the Pleistocene populations of Chionomys nivalis and Lasiopodomys gregalis of the medium-altitude mountain locations into the Early Epi-Atlantic.

\section{Diet of Tyto alba}

The church of Saint Stephen the King nowadays stands amidst a residential estate near the Žilina downtown, but some 500 years ago it served for several surrounding villages in the western rural environs of the city. The relatively numerous sample set of pellets of the barn owl (Tyto alba) from this locality, dated back to the early Modern Age (ca. 1500 AD), is composed of a high proportion of five mice species (Mus musculus, Apodemus sp.) and a relatively low incidence of the field vole (Microtus arvalis; 27.0\%). The Recent samples of the diet of this owl species from the neighbouring Turčianska kotlina Basin are dominated by M. arvalis (78.5\%), whereas other species of the open landscape (e.g. Apodemus uralensis, Crocidura leucodon) are absent (Table 6).

The composition of the barn owl diet in 100-year-old remnants found in the valley of the Bodva River below the cave near Hatiny was dominated by the family Muridae (Table 7) and a low proportion of Microtus arvalis $(27.8 \%)$, and most importantly, by a great incidence of the root vole (Alexandromys oeconomus) and southern birch mouse (Sicista trizona). In the sample set collected in the Košická kotlina Basin in the Recent period, the field vole is predominant (54.6\%), while Alexandromys oeconomus and Sicista trizona are missing. 
Table 5. Proportions of particular mammal species in fossil remains of diet of the tawny owl (Strix aluco) of different age of the Holocene period from the Tlstá Massif (Vel'ká Fatra Mts., northern Slovakia). Legend: B - Boreal, EA - Epi-Atlantic, SA - Sub-Atlantic, SR - Sub-Recent, R - Recent

\begin{tabular}{|c|c|c|c|c|c|c|c|c|}
\hline species $\backslash$ period & B & & $\mathrm{EA}$ & SA & SR & $\mathrm{R}$ & total & $\%$ \\
\hline Lasiopodomys gregalis & $4+164$ & $1-$ & 2 & $4-$ & $3-$ & $4-$ & 166 & 4.30 \\
\hline Dicrostonyx gulielmi & $3+\quad 39$ & & 6 & $2-$ & $1-$ & $3-$ & 45 & 1.16 \\
\hline Chionomys nivalis & & & & & & & 9 & 0.23 \\
\hline Apodemus uralensis & $1-$ & $1+$ & 10 & $1+47$ & $1+\quad 46$ & 4- & 103 & 2.67 \\
\hline Apodemus flavicollis & $3-$ & & 36 & $1+381$ & $2-\quad 39$ & 293 & 753 & 19.49 \\
\hline Apodemus agrarius & & & 5 & $1+\quad 17$ & 4 & $2-$ & 26 & 0.67 \\
\hline Muscardinus avellanarius & $1-$ & & 15 & $1+\quad 99$ & $2-$ & 92 & 218 & 5.64 \\
\hline Glis glis & $1-$ & & 4 & $1+\quad 62$ & $2-$ & 56 & 124 & 3.21 \\
\hline Eliomys quercinus & & & 2 & $1+\quad 14$ & 2 & $1-$ & 18 & 0.47 \\
\hline Micromys minutus & & & 2 & $1+\quad 12$ & 4 & $1-$ & 18 & 0.47 \\
\hline Cricetus cricetus & & & 6 & $1+\quad 39$ & $1-$ & $3-$ & 45 & 1.16 \\
\hline Arvicola amphibius & & & 2 & $1+\quad 18$ & 4 & $1-$ & 26 & 0.67 \\
\hline Microtus agrestis & & & & $1+\quad 10$ & & 4 & 14 & 0.36 \\
\hline Nyctalus noctula & 1 & & 2 & $1+\quad 16$ & 2 & $1-$ & 21 & 0.54 \\
\hline Apodemus sylvaticus & $1-$ & & & $1-\quad 16$ & $2+\quad 58$ & $3-$ & 75 & 1.94 \\
\hline Microtus arvalis & $3-$ & & 19 & $1-152$ & $2+291$ & $2-83$ & 547 & 14.16 \\
\hline Myodes glareolus & $2-$ & & 9 & 93 & $4-$ & $1+152$ & 255 & 6.60 \\
\hline Sorex araneus & 6 & $1-$ & 1 & $2-$ & $3-$ & $1+128$ & 151 & 3.91 \\
\hline Sorex minutus & & & 1 & 6 & 1 & $1+\quad 20$ & 28 & 0.72 \\
\hline Talpa europaea & 1 & & 5 & 30 & $1-$ & 29 & 69 & 1.79 \\
\hline Mustela nivalis & 2 & & 3 & 7 & 2 & $1-$ & 14 & 0.36 \\
\hline Mus cf. musculus & & & 2 & 12 & 7 & $1-$ & 22 & 0.57 \\
\hline Pipistrellus pipistrellus & & & 3 & 6 & 2 & $1-$ & 11 & 0.28 \\
\hline$\overline{\text { Microtus subterraneus }}$ & & & 4 & 13 & 3 & 15 & 35 & $0 . \overline{91}$ \\
\hline Vespertilio murinus & 1 & & 2 & 13 & 5 & 5 & 26 & 0.67 \\
\hline Crocidura suaveolens & & & 2 & 7 & 1 & & 10 & 0.26 \\
\hline Sorex alpinus & & & & 2 & & 7 & 9 & 0.23 \\
\hline Eptesicus serotinus & & & 1 & 6 & 1 & 1 & 9 & 0.23 \\
\hline Myotis myotis & & & & 1 & 1 & 4 & 6 & 0.16 \\
\hline Microtus tatricus & & & & 4 & 1 & 1 & 6 & 0.16 \\
\hline Dryomys nitedula & 1 & & 1 & 3 & & & 5 & 0.13 \\
\hline Neomys anomalus & & & & 4 & & 1 & 5 & 0.13 \\
\hline Crocidura leucodon & & & 1 & 2 & 1 & & 4 & 0.10 \\
\hline Mammalia, 50 species & $1+238$ & & 147 & 1,123 & 502 & $1-897$ & 2,907 & 75.23 \\
\hline Aves, 54+ species & $2-$ & $1+$ & 22 & $1+120$ & 44 & $1-\quad 48$ & 234 & 6.60 \\
\hline Amphibia, Reptilia, Pisces & $3-$ & $1-$ & 13 & $1-\quad 95$ & $1+96$ & $1+255$ & 459 & 11.88 \\
\hline Evertebrata & $3-$ & $2-$ & 0 & $5-$ & $4-$ & $2+264$ & 264 & 6.83 \\
\hline & 23 & & 18 & 1,338 & 642 & 1,464 & 3,864 & 100.00 \\
\hline diversity (H') & 1.17 & & 3.11 & 3.02 & 2.50 & 3.10 & & \\
\hline
\end{tabular}

The Sub-Recent sample set of the diet of Tyto alba from the church of Saint Stephen the King was dated to the early 16th century based on the dendrochronology of the oldest wooden beams in the roof structure (OBUCH \& Dorica 2011, ОвUCH et al. 2016). Dating of the bones by means 
Table 6. Proportions of particular mammal species in the remains of diet of the barn owl (Tyto alba); comparison of sample sets from a subrecent material (15th century) collected in a church in Žilina (northern Slovakia) with a recent material from Turiec (northern Slovakia) and Tekov (south-western Slovakia)

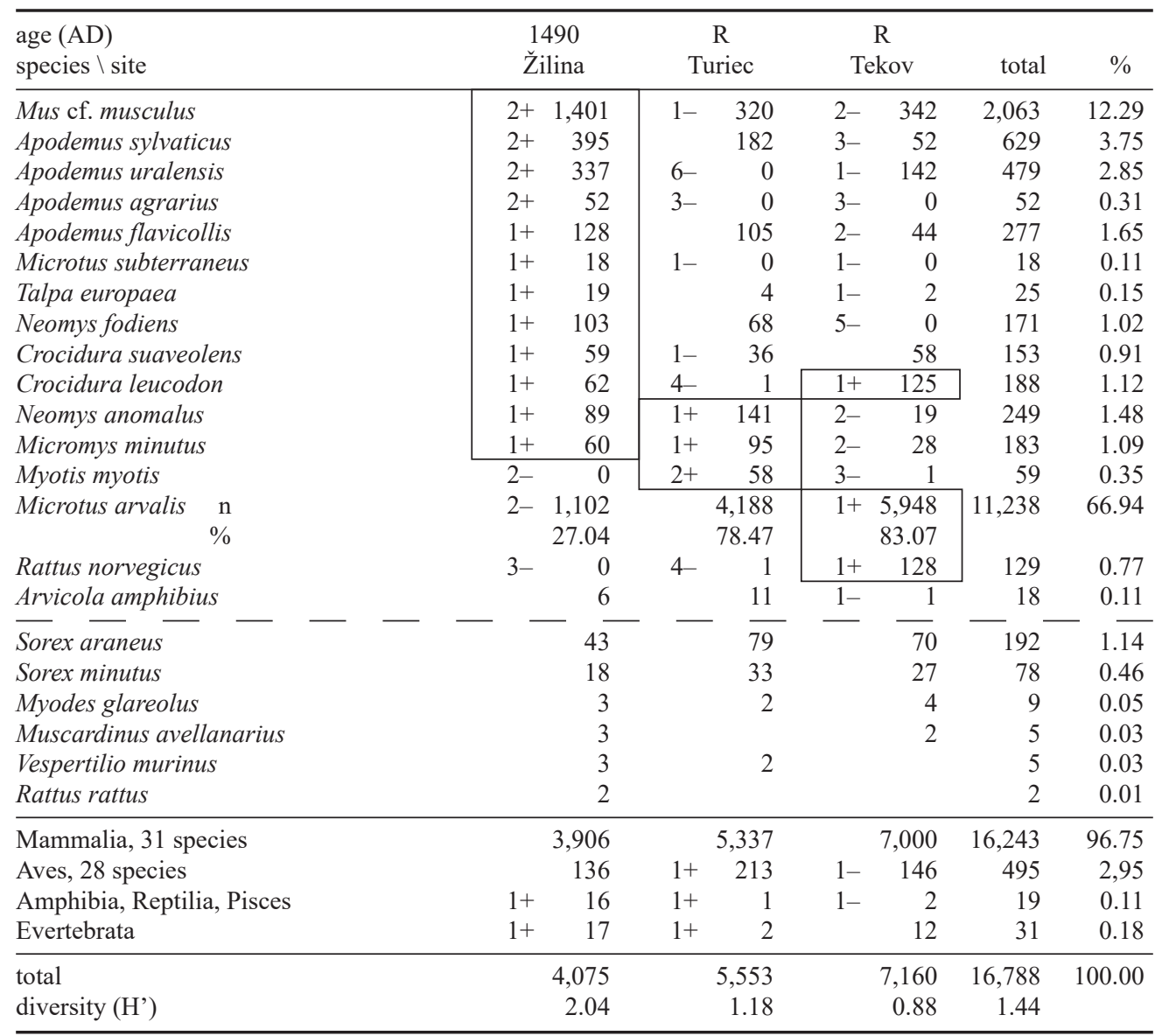

of the ${ }^{14} \mathrm{C}$ analysis specified the sample age as from the turn of the 15 th and 16 th centuries. The barn owls used the empty beam sockets in the church walls following a fire until the time when the roof was rebuilt. Judging from the amount of food remains found (4,075 pieces of prey), the owls nested there for at least 20 years.

The age of the sample set of Tyto alba prey from Hatiny was estimated to between 60 and 200 years BP, since I found remnants of organic material in the nest which turned out to be animal fur, considerably humidified in the damp environment of the cave (ОвUCH 1992, ОвUCH et al. 2016). The dating of the bones using the ${ }^{14} \mathrm{C}$ analysis confirmed this estimate. 


\section{Diet of $B u b o \quad b u b o$}

At the Sokol Rock on Žiar Mts. on the western side of the Turčianska kotlina Basin, a destroyed eagle owl nest was discovered that was dated $1890 \pm 50$ AD. The analysis of the bone remains found there showed a relatively higher proportion of murid rodents and frogs (Amphibia), i.e. fairly small prey species for Bubo bubo (Table 8). The material collected in 1976 and again in 1994 and later from two eagle owl nests in the Moškovské skaly Rocks contained a high proportion of medium-sized mammals, especially Rattus norvegicus, Arvicola amphibius, Erinaceus roumanicus, Lepus europaeus, and Mustela nivalis. The proportion of birds (Aves) was

Table 7. Proportions of particular mammal species in the remains of diet of the barn owl (Tyto alba); comparison of sample sets from a subrecent material (19th century) found near Hatiny (eastern Slovakia) with a recent material from the Košická kotlina Basin (eastern Slovakia)

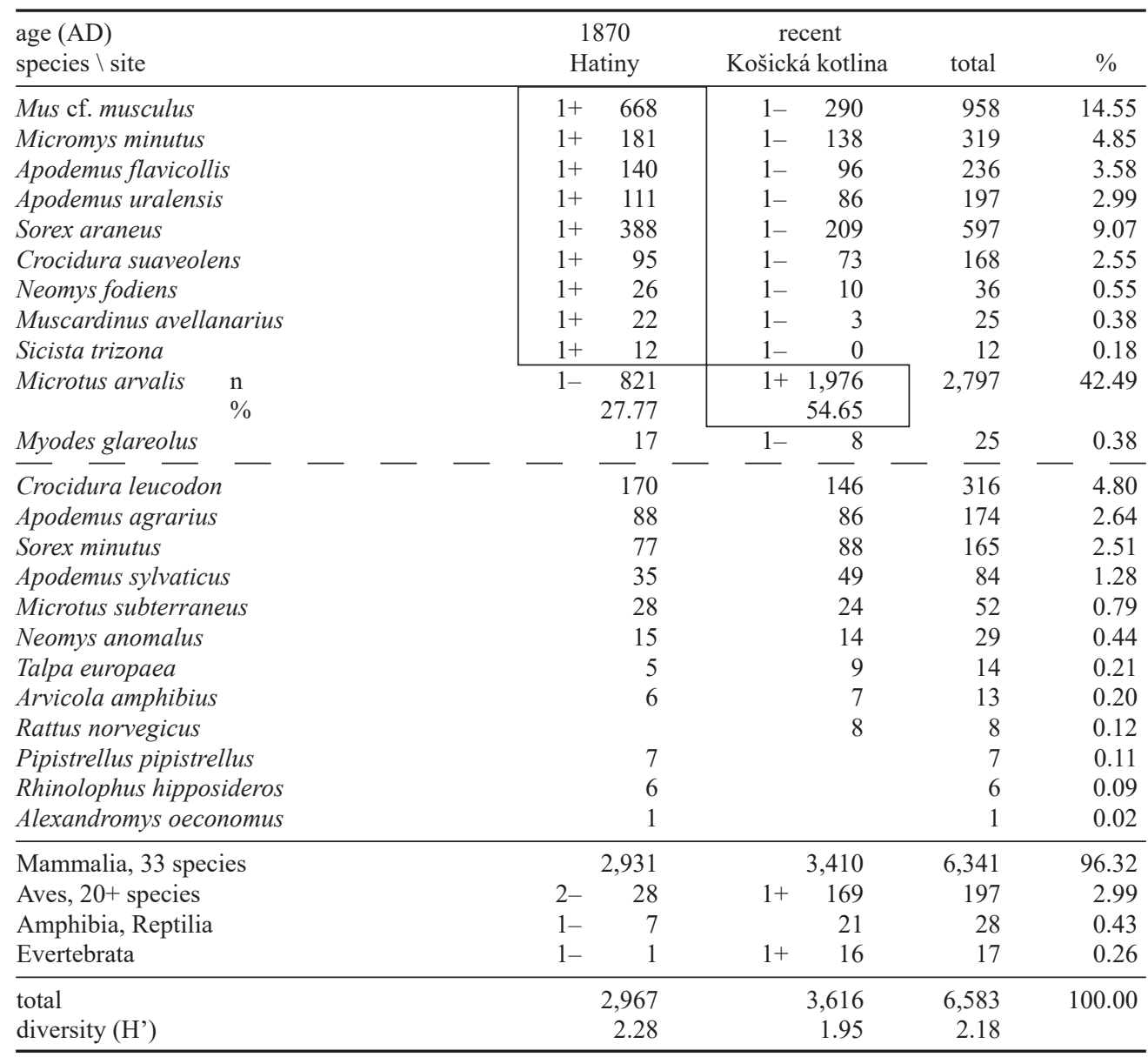


Table 8. Proportions of particular mammal species in the remains of diet of the eagle owl (Bubo bubo) in the Turiec part of the Žiar Mts. (central Slovakia) from sample sets representing a period of more than a century

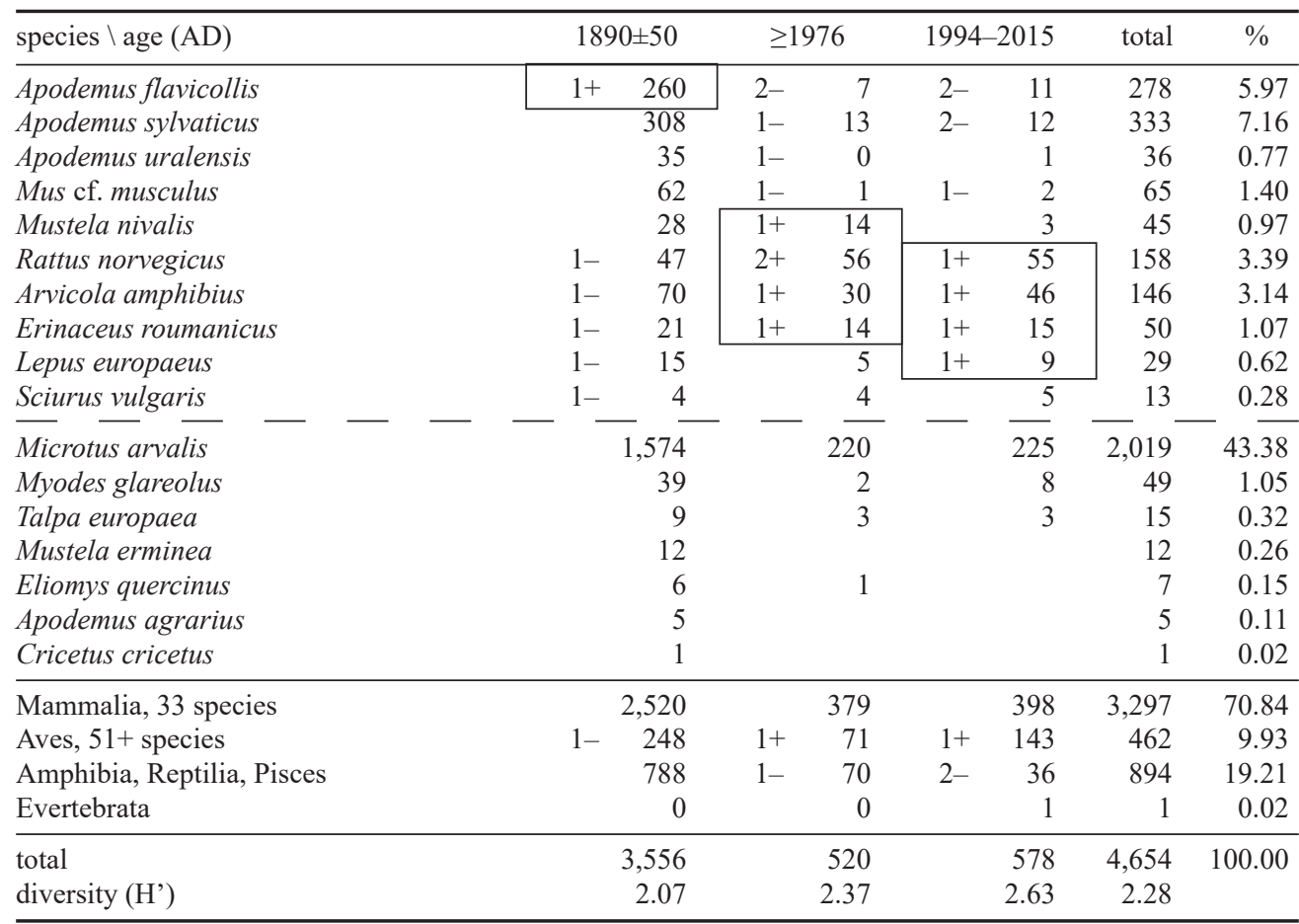

relatively high in that period, while that of frogs was rather small. A century ago the common hamster (Cricetus cricetus) and spadefoot toad (Pelobates fuscus) inhabited the Turiec region. The field vole (Microtus arvalis) showed relatively stable incidence of $>40 \%$ in all sample sets under comparison.

Great differences in the eagle owl prey size were found also in the Liptovská kotlina Basin. During the period of Wallachian colonisation (16th-19th centuries), extensive areas of upper slopes in the valleys of the Low Tatra Mountains were deforested. We found eagle owl nests dating from that period deep in the Demänovská dolina Valley, Jánska dolina Valley and below the village of Malužiná. The predominance of the common brown frog Rana temporaria at these sites exceeded $75 \%$ (Tab. 9). A find dating from that period on the border of the mountains near Liptovský Ján featured a higher proportion of three species of wood mouse Apodemus and numerous records of the common hamster C. cricetus. An eagle owl nest from the 1970s located near Liptovský Hrádok had a markedly greater share of larger prey: L. europaeus, M. nivalis, A. amphibius, and $R$. norvegicus. The share of the field vole M. arvalis was higher there, whereas the proportion of frogs dropped by half to $36.7 \%$. Five samples of eagle owl pellets collected 


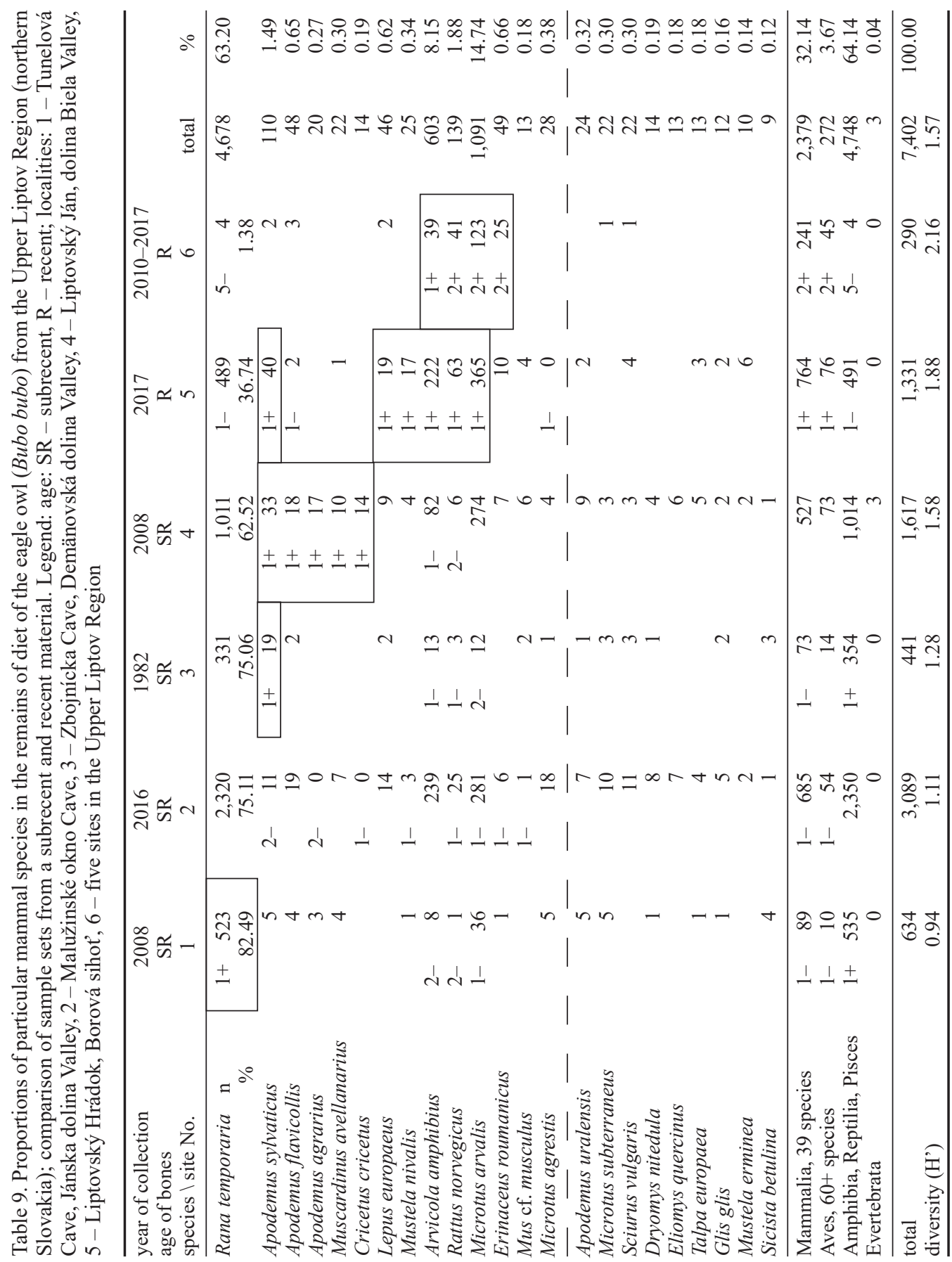


in the Upper Liptov region after 2010 had only a low proportion of $R$. temporaria $(1.4 \%)$, but large amounts of the white-breasted hedgehog E. roumanicus and considerable predominance of $M$. arvalis remains.

Significant changes in the composition of small-mammal fauna occurred in farmland 60-70 years ago during the period of the communist regime-induced changes in agriculture that led to the removal of field borders and consolidation of arable land, draining of moist pastures, and the application of chemical fertilizers and pesticides. These changes benefitted field voles (Microtus arvalis) to the detriment of murine rodents. The same period also witnessed fundamental changes in the foraging strategy of Bubo bubo. They moved out of the mountain valleys into the borders of river basins due to changes in land use involving recategorization of farmland as forestry plots, with subsequent afforestation of the hillsides. Livestock became concentrated into mass sheds at the outskirts of villages, where the eagle owls could then hunt the Norway rats (Rattus norvegicus). In the period after 1990, such type of management was mostly abandoned and unused pastures became woodlands, reducing the extent of open hunting grounds for raptors including the eagle owls, and increasing the incidence of forest rodent species (Apodemus flavicollis, Myodes glareolus). Similar trends can be found in many parts of Slovakia (Овuch 2017, 2018, KudLA et al. 2019).

\section{Conclusive notes}

In this study I present the data on predator diet suggesting changes over time in the spectrum of mammalian fauna occurring in several parts of Slovakia. These changes are more or less pronounced in connection with the foraging strategies of the particular raptor species. Individual diet sample sets consisted of bones accumulated in relatively short time periods associated with the raptor's occupation of specific nesting or roosting places. These places are distinguished according to the specific behavioural characteristics of the predator species.

The classical excavations of deposits from the Holocene period enable identification of the predator species responsible for the accumulation of bones, for instance Bubo bubo in the case of the Brálie Nature Reserve (DAROLA \& LožEK 1982) or Strix aluco in the Maštal'ná jaskyňa Cave (LOŽEK \& HORÁČEK 1988). However, errors occasionally occur in the determination of predator identity or the age of the finding, for instance in the study by SCHAEFER (1974), who supposed the finding from the Murán̆ I Cave to represent prey remains of Bubo bubo from the 18th century, whereas ОвUсн (2012) suggested it was rather produced mainly by Strix aluco in the Middle Holocene.

The Pleistocene sample sets were collected from the localities of rather high altitudes $(>800 \mathrm{~m}$ a. s. 1.) in the mountain ranges of central Slovakia. PoKORNÝ et al. (2015) concluded that even during the coldest periods of the Late Pleistocene, the complex landscapes of the Western Carpathians featured warmer places (refuges) in which certain more thermophilous species of flora and fauna could survive. The fossil fauna found in the sample set from the Sarkanica Cave on the southern slope of the Muránska planina Mts. could have remained protected in warmer, sheltered places in the Muránka River Valley. The profile taken from the Peskö Cave at the place where a stream enters the Rimavská kotlina Basin revealed the remains of relatively thermophilous fauna with an abundance of Microtus arvalis (LožEK et al. 1989). Similar thermophilous species were found in a profile taken from a cave in the Dzeravá skala Rock in the Malé Karpaty Mts. (HoRÁČEK 2005). 


\section{REFERENCES}

BENDík A., 2018: Súčasný stav paleontologických výskumov v jaskyniach Vel'kej Fatry [The current status of palaeontological research in caves of the Vel'ká Fatra Mts.]. Slovenský Kras, 56: 117-127 (in Slovak).

DAROLA J. \& LožEK V., 1982: Kvartérní fauna a stratigrafie převisu v rezervaci Brálie u Malých Kršteňan [The Quaternary fauna and stratigraphy of a rock-shelter in the Brálie State Nature Reserve near Malé Kršteňany]. Československý Kras, 33: 53-67 (in Czech).

HoRÁČEK I., 2005: Small vertebrates in the Weichselian series in the Dzerava skala Cave: List of the samples and brief summary. Pp.: 157-167. In: Kaminská L., KozŁowski J. K. \& Svoboda J. A. (eds.): Pleistocene Environments and Archeology of the Dzeravá skala Cave, Lesser Carpathians, Slovakia. Polska Akademia Umiejętności, Kraków, 226 pp.

Kadlečí́ J., Dudich A., Obuch J. \& Štollmann A., 1995: K faune cicavcov (Mammalia) Belianskej doliny a rezervácie Borišov vo Vel'kej Fatre [On the mammal fauna (Mammalia) of the Belainska dolina Valley and the Borišov Reserve in the Vel'ká Fatra Mts.]. Ochrana Prírody, 13: 311-320 (in Slovak).

Kaizer J., Obuch J., Kontul I., Šivo A., Richtáriková M., Čech P. \& Povinec P. P., 2018: Methods of radiocarbon determination in wine and bone samples by gas proportional counting technique. $R a-$ diocarbon, 2018: 1-11.

Kudla M., HolúBeK P., OBUCH J. \& LiTva J., 2019: Základná speleologická a zoologická charakteristika jaskýň v oblasti brál Mladucha v Komorníckej doline, Nízke Tatry [Basic speleological and zoological characteristics of the cave in the Mladucha area of the Komornícka dolina Valley, Nízke Tatry Mts.]. Slovenský Kras, 57: 177-196 (in Slovak).

LožEK V., 1973: Př́roda ve čtvrtohorách [The Nature in Quaternary]. Academia, Praha, 372 pp (in Czech).

LOŽEK V. \& HorÁČEK I. 1988: Vývoj přírody Plešivské planiny v poledové době. [Development of nature on the Plešivecká planina Plateau during the postglacial period]. Ochrana prírody, Výskumné práce z ochrany prírody, 6 A: 151-175.

LožEK V., GAÁL L., Holec P. \& HorÁČeK I., 1989: Stratigrafia a kvartérna fauna jaskyne Peskö v Rimavskej kotline [The stratigraphy and the Quaternary fauna of the Peskö Cave in the Rimavská kotlina Basin]. Slovenský Kras, 27: 29-56 (in Slovak).

Овисн J., 1992: Potrava sov v okolí Moldavy nad Bodvou [The diet of owls in vicinity of Moldava nad Bodvou]. Pp.: 190-197. In: Fulín M. (ed.): 15. Východoslovenský tábor ochrancov prírody. Prehl'ad odborných výsledkov [15th East-Slovakian Camp of the Nature Protectors. Overview of the Special Results]. OV SZOPK \& OÚ ŽP Košice-vidiek, Moldava nad Bodvou, 221 pp (in Slovak).

OвUсн J., 1995: Nové poznatky o výskyte netopierov v jaskynných tanatocenózach [New data on the occurence of bats in cave thanatocoenoses]. Netopiere [Revúca], 1: 29-38 (in Slovak).

OвUCн J., 2000: Fosílna fauna v jaskyni Šarkania diera v Súl'ovských skalách [Fossil fauna in the Šarkania diera Cave in the Súl'ovské skaly Mts. (Northwest Slovakia)]. Slovenský Kras, 38: 165-170 (in Slovak).

OвUсн J., 2001: Using marked differences from the mean (MDFM) method for evaluation of contingency tables. Buteo, 12: 37-46.

Oвuch J., 2002: Potrava sov v oblasti Tatier - 65-ročná história výskumu [The diet of owls in the Tatra region - 65 year history of research]. Oecologia Montana, 11: 77-81 (in Slovak).

Oвuch J., 2006a: Subfosílna a subrecentná potrava sovy obyčajnej (Strix aluco) vo Vel'kej Fatre [The subfossil and subrecent diet of the tawny owl in the Vel'ká Fatra Mts.]. Pp.: 225-235. In: Adamec M. \& Urban P. (eds): Výskum a ochrana cicavcov na Slovensku VII. Zborník referátov z konferencie (Zvolen 14.-15. 10. 2005) [Research and Protection of the Mammals in Slovakia VII. Proceedings of a Conference (Zvolen 14-15 October 2005)]. ŠOP SR, Banská Bystrica, 239 pp (in Slovak).

Овисн J., 2006b: Fosílna potrava belane tundrovej (Nyctea scandiaca) v jaskyni Šarkanica [Fossil diet of the snowy owl (Nyctea scandiaca) in the Šarkanica Cave]. Reussia, 3(2): 160 (in Slovak).

OвUсн J., 2011: Spatial and temporal diversity of the diet of tawny owl (Strix aluco). Slovak Raptor Journal, 5: 1-120.

Овисн J., 2012: Helmut Schaefer importance for the knowledge of the development of the Tatra Mts. fauna. Lynx, n. s., 43: 197-200. 
OBuch J., 2017: Časové zmeny v potrave výra skalného (Bubo bubo) v Žilinskej kotline [Temporal changes in the diet of the Eurasian eagle owl (Bubo bubo) in the Žilinská kotlina Basin, NW Slovakia]. Pp.: 47-49. In: KalAš M. \& KicKo J. (eds.): Výskum a ochrana Malej Fatry. Zborník referátov z konferencie, Gbel'any, 5. Október 2017 [Research and Protection of the Malá Fatra Mts. Proceedings of a Conference, Gbel'any, 5 October 2017]. Správa NP Malá Fatra, Varín, 112 pp (in Slovak).

ОвUсн J., 2018: Príklady časových zmien v pomernom zastúpení koristi u výra skalného (Bubo bubo) na Považí [Examples of temporal changes in the diet of the Eurasian eagle owl (Bubo bubo) in the Považie Region]. P.: 15. In: KROPIL R. \& LeŠo P. (eds.): Aplikovaná ornitológia 2018 - Zborník abstraktov [Applied Ornithology 2018 - Abstract Book]. Lesnícka fakulta Technickej univerzity, Zvolen, 22 pp (in Slovak).

OвUсн J., 2019: Fauna vtákov a drobných cicavcov z konca pleistocénu v jaskyniach Vel'kej Fatry [Birds and small mammals dated to the end of Pleistocene found in the caves of Vel'ká Fatra Mts.]. Slovenský Kras, 57: 75-81 (in Slovak).

ObUCh J., DANKo Š. \& Noga M., 2016: Recent and subrecent diet of the barn owl (Tyto alba) in Slovakia. Slovak Raptor Journal, 10: 1-50.

Obuch J. \& Darola J., 1980: Poznatky o zložení a vývoji teriofauny Gaderskej doliny na základe osteologických nálezov [Data on the composition and evolution of theriofauna of the Gaderská dolina Valley based on the osteological deposits]. Ochrana Prírody, 3C: 325-354 (in Slovak).

Obuch J. \& Dorica J. 2011: Potrava plamienky driemavej (Tyto alba) zo 16. storočia v Kostole Sv. Štefana král'a v Žiline - Dolných Rudinách [The diet of the barn owl (Tyto alba) from the 16th century in the St. Stephan church in Žilina - Dolné Rudiny]. Pp.: 164. In: Bryja J., Řehák Z. \& ZuKAL J. (eds): Zoologické dny Brno 2011. Sbornik abstraktiu z konference, 17.-18. února 2011 [Zoological Days 2011. Abstract Book of a Conference, 17-18 February 2011]. Ústav biologie obratlovců AV ČR, Brno, 282 pp (in Slovak).

POKORNÝ P., JANKOvSKÁ V. \& HoRÁČEK I., 2015: České Hercynikum versus Západní Karpaty: klíčové biogeografické rozhraní Evropy v posledním glaciále [Bohemian Hercynides versus Western Carpathians: A crucial biogeographic boundary of Europe during the last glacial epoch]. Zprávy České Botanické Společnosti, 50: 165-180 (in Czech).

Portenko L. A., 1972: Die Schnee-Eule, Nyctea scandiaca. Die Neue Brehm-Bücherei 454. A. Ziemsen Verlag, Wittenberg-Lutherstadt, $232 \mathrm{pp}$.

Royer A., Montuire S., Gilg O. \& Laroulandie V., 2019: A taphonomic investigation of small vertebrate accumulations produced by the snowy owl (Bubo scandiacus) and its implications for fossil studies. Palaeography, Palaeoclimatology, Palaeooecology, 514: 189-205.

Sabol M., Bendík A., Grivalský M., GrivalskÝ M. \& LizÁK J., 2014: Lates and highes fossil record of cave bears (Ursus ex gr. spelaeus) in Slovakian Western Carpathians. Quaternary International, 339-340: 189-196.

SCHAEFER H., 1974: Eine Fauna der Hohen Fatra aus dem 18. Jahrhundert (= Muran I). Bonner Zoologische Beiträge, 25: 231-282.

SchAEFER H., 1975: Die Spitzmäuse der Hohen Tatra seit 30000 Jahren (Mandibular Studie). Zoologischer Anzeiger, 195: 89-111.

Smirnov N. G., Izvarin E. P., Kuzmina E. A. \& Kropacheva Y. E., 2015: Steppe species in the late Pleistocene and Holocene small mammals community of the Urals. Quaternary International, 420: 136-144.

ŠIPöcz T., 2004: Zber. Databázový program. Verzia 3. [Zber. A Database Software. Version 3]. Botanical Garden, Comenius University, Blatnica.

Wilson D. E., Lachner T. E. \& Mittermeier R. A. (eds.), 2016: Handbook of the Mammals of the World. Volume 6. Lagomorphs and Rodents I. Lynx Edition, Barcelona, 987 pp.

Wilson D. E., LAChNer T. E. \& MitTermeier R. A. (eds.), 2017: Handbook of the Mammals of the World. Volume 7. Rodents II. Lynx Edition, Barcelona, 1008 pp. 